\title{
Heating and ventilation of historic churches: the University Church - case study
}

\author{
Ewa Pałupska ${ }^{1, *}$, and Paulina Kanaś ${ }^{1}$ \\ ${ }^{1}$ Wrocław University of Science and Technology, Faculty of Environmental Engineering, \\ Wybrzeże Wyspiańskiego 27, 50-370 Wrocław, Poland
}

\begin{abstract}
The paper presents the basic issues related to heating and ventilation of historic sacred buildings based on a review of available literature. It gives guidelines for designing and calculation method of useful heat demand as well as shows vulnerable issues which must be considered during designing process. The article focuses on pros and cons of warm air heating and low temperature radiant heating ("friendly heating"). The applicability of using these heating methods in the University Church in Wrocław (Poland) was considered.
\end{abstract}

\section{Introduction}

Heritage buildings constitute an important historical and cultural value of human's activity. They can be defined as objects at a certain age under legal preservation. A particular kind of heritage buildings are sacred objects. There are a few basic constructional and architectural features that characterize most of the sacred historical buildings in Poland: wide, uninsulated walls with large heat capacity, lots of high, single glazed windows with high heat transfer coefficient, high monumental rooms with large cubature comparing to a very small zone occupied by people. It is also possible to notice one more characteristic feature of the sacred buildings being a consequence of their function - churches are occupied periodically and temporarily by the variable number of people. Interior equipment preserved in churches also is an important issue. It usually consists of valuable artefacts such as carvings, paintings, liturgical items and organs [1,2].

\subsection{Microclimate in the historical churches}

Generally microclimate can be defined as specific physical conditions such as temperature and relevant humidity $(\mathrm{RH})$ in limited space. The indoor microclimate of an unheated building fallows to some extent the outdoor climate. The specific constructional features of most of the churches in Poland cause partial reduction of influence of outdoor environmental conditions' changes on current indoor conditions [3]. Fluctuations of parameters being a result of temporary presence of people are largely reduced by big cubature of the building. The natural microclimate of unheated space maintained this way

\footnotetext{
${ }^{*}$ Corresponding author: ewa.palupska@gmail.com
} 
for the centuries caused that the equipment and valuable artworks have been acclimatized to these indoor environment and are preserved in good condition [4].

\section{Heritage conservation and thermal comfort in churches}

Nowadays thermal comfort is becoming more and more important issue. In the climate of Poland maintaining thermal comfort of people during relatively cold winters is strictly connected with implementation of heating system. In the case of the historical buildings it can be very problematic. Church space heating causes changes in a climatic condition comparing to the natural microclimate. Because of the heating, $\mathrm{RH}$ level drastically decreases and as a result it can cause evident damage of the artefacts.

The ranges of the air parameters optimal for keeping thermal comfort of people for light physical activity and for preserving the majority of artworks are not compatible with each other. The Mollier diagram (see Fig. 1) shows these ranges [2, 5, 6]. Therefore it is necessary to set priorities at the beginning of designing process of any HVAC system, which will have an influence on the natural microclimate of the church.

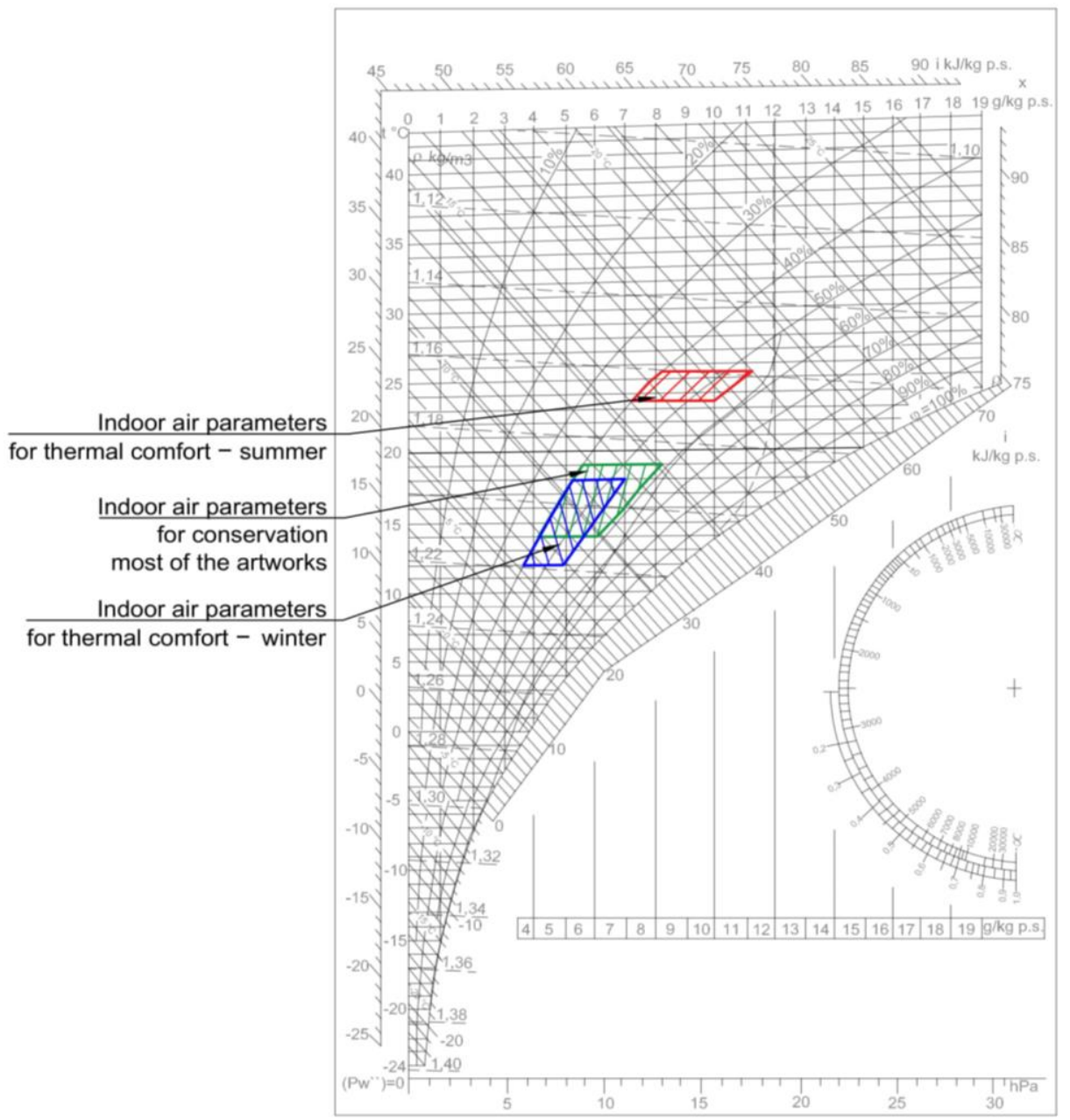

Fig. 1. The Mollier diagram with ranges of the indoor air parameters. 
Controlling the air parameters in the historical buildings including churches should be primarily focused on preserving the valuable artefacts intact. It may be achieved through keeping indoor conditions as close as possible to unaffected microclimate called "historical preservation climate" [7]. It is absolutely required to perform monitoring of air parameters in the unheated building before installing any heating system [8].

Every change of indoor air parameters, especially short-term but intense, can have negative impact on historical objects' condition (both building and equipment). Many kind of valuable artworks preserved in churches differ from each other with demanded optimal air parameters and have a specific vulnerability to fluctuations of these parameters. A lot of studies have proved that RH is the essential parameter to consider, secondly temperature [9]. Air circulation and dew point are also important factors.

Objects made of hygroscopic materials are particularly sensitive to RH variation (wood, textile, leather, painting layer). Wooden carvings, confessionals and pews can be damaged with cracking or swelling. Paintings on canvas and polychromies are subjected to cracking and soiling, additionally their surface can be covered with mold. In case of condensation formed on internal surfaces of walls and cold objects, mold (textiles, wood, leather) and corrosion (metal elements) can appear. Organs are often one of the most valuable and specific artefacts in many churches. They are made of a few materials (wood and metal) that have different hygroscopic properties. For that reason they are extremely sensitive to any fluctuation of parameters of the ambient air. RH variation can cause damage of wooden elements and corrosion of metal elements. High temperature difference between environment and insides of the instruments can have an impact on intensification of detuning. Intensified air circulation in the church contribute to spread of dust. Additionally, when condensation on the elements inside the church appears, the walls and sculptures are subjected to blackening [8].

\subsection{Heating in churches}

When choosing a heating system to install in the historical sacred building, it is important to consider following issues: conservation requirements, thermal comfort and economy [9]. Generally, it is possible to divide heating systems into categories due to the range of influence and the period of influence.

There are two basic heating methodologies. The first one increases temperature in the whole cubature of the church - it can be implemented through e.g. central heating. The second type of heating system warms only zones occupied by people but keeps the building cool - it needs localized heat sources [10].

Heating systems can be executed via different time programmes:

- continuous heating - heats the space of the church irrespective of occupancy, therefore the level of $\mathrm{RH}$ decreases, so it is not recommended in regions with cold and dry winters,

- intermittent heating - heating works directly before and/or during services, causes cyclic variations of temperature and RH level, guarantees mediocre thermal comfort, but it is characterized by lower energy consumption comparing to the continuous heating,

- continuous heating to a setback temperature - heating works continuously to keep the requested setback temperature and heats up the room periodically to the temperature of thermal comfort during services [10].

Choosing the heating system should be preceded by thorough analysis including factors such as: outdoor climate, current indoor microclimate and its impact on condition of equipment, conservation requirements, technical capabilities of implementation the heating system, costs of installing and maintaining the system. 


\section{Calculations - guidelines, methodology and problems}

\subsection{Assumptions for heating the church}

Susceptible artefacts require different air parameters than a human body. A compromise put toward by the [11] suggests that the air temperature inside a church should be within the range from $12^{\circ} \mathrm{C}$ to $15^{\circ} \mathrm{C}$. There is also a recommendation that $\mathrm{RH}$ cannot be kept beyond the range of $45-75 \%$, regardless of the historical reference climate. The variation of temperature over time should not exceed $1.5 \mathrm{~K} / \mathrm{h}$.

\subsection{Useful heat demand}

There are no unambiguous guidelines for determining the useful heat demand of the churches. Nevertheless, in the literature [11] there is the calculation method described, that considers a division building's components under the heat storage criterion. The method defines windows, doors and ceiling as non-heat-storage elements, whereas walls, floor and columns are able to store heat. Ventilation heat losses are calculated on the basis of the air volume flow rate. Total heat demand is the sum of the heat losses through ventilation and all building's components.

\section{Heating methods}

\subsection{Warm air heating}

Warm air heating system heats both the congregation and the equipment through warm air. In general, heat tends to rise causing convective flows. One of the effects of this natural process is stratification with the consequences of changing RH level, overheating ceiling (and upper parts of walls) and heat losses through a roof. The second one is mixing an internal air, which affects the increase in deposition rate of pollutants (surface blackening) and the cold downdrafts formed in the proximity of walls [10]. Another important issue is to limit blowing speed to $2 \mathrm{~m} / \mathrm{s}$ and temperature of injected air to $45^{\circ} \mathrm{C}$. It is also essential to provide that the sound power level does not exceed $35 \mathrm{~dB}(\mathrm{~A})$ [11]. Moreover, in most cases disruption of floor and walls caused by assemblage of ducts, pipes and grilles is unacceptable in the historic buildings. The low operating costs and reasonable short heating time also belong to the advantages of warm air heating system [10].

\subsection{Low temperature radiant heating}

An alternative solution of the heating method is a system specifically studied for conservation with the European Friendly-Heating project. The aim is to warm people without an environmental impact. This option is based on the low temperature radiant heaters, strategically placed in pews or on a floor (to keep heat localized). The heaters emit infrared radiation, which warms only the surfaces, leaving air temperature unaffected, so the T-RH perturbation doesn't exceed natural fluctuations. This is why artworks remain in safe conditions. The most dangerous problems that occur during warm air heating (overheating vault, spread of contamination, strong cold downdrafts) are eliminated [10]. However, there is no real way to control a moisture level without mechanical ventilation. Note that this system is turned on while a service starts (or only a few minutes earlier). It is 
an advantage, because there is no need to heat while people are absent and a disadvantage, because there is no possibility to store heat or to use lower priced electricity (night time).

The solution is based on electric power, that is considered to be the most expensive heat source. Execution of the electric heating must take due account of the current-carrying capacity of the existing electric cables. There is a possibility that new electricity consumption (using electric heaters) exceed this value. As a result it might be essential to alter the electrical installation and change the contracted power. These measures are related to increase in costs. Greater attention should therefore be paid to the technical feasibility.

Another drawback of "friendly heating system" may be high operating costs. There are, however, some measures for reducing electricity consumption without compromising functionality. These actions are switching off radiant heaters 5-10 minutes before the end of a service and zoning of heating (the number of active devices depends on the attendance of people) $[10,12]$.

\section{The University Church in Wrocław - case study}

\subsection{The current state}

The University Church of the Blessed Name of Jesus is located in Wrocław. The average monthly parameters of the outside air ( $\mathrm{T}$ and $\mathrm{RH}$ ) in Wrocław were shown in Figure 2, developed on the basis of the climate data [13]. Winter is relatively cold with a very high RH level (from 80 to $85 \%$ ), but also low absolute humidity. During summer the average temperature ranges from 12 to $17^{\circ} \mathrm{C}$ and $\mathrm{RH}$ varies from 50 to $80 \%$ (averagely $75 \%$ ).

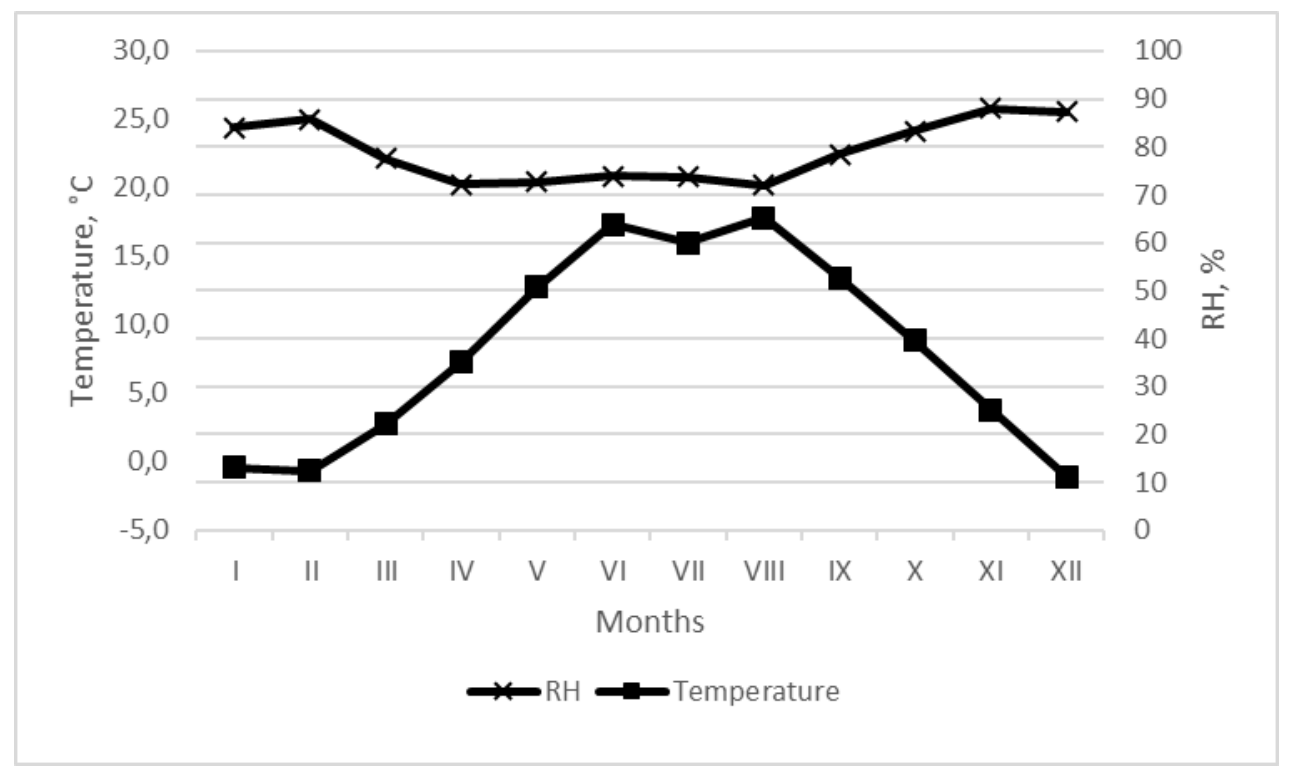

Fig. 2. The average outside air parameters in Wrocław.

The Church was built in the $17^{\text {th }}$ century. The baroque interior covered with paintings is filled with the organs, the frescos and the antique confessionals adorned with sculptures. Therefore the church obtained the entry into the register of monuments under the number $290 / 85$ [14]. The church is $52 \mathrm{~m}$ long, $27 \mathrm{~m}$ wide and $23.55 \mathrm{~m}$ high (at the barrel vault) and has the total volume of around $36250 \mathrm{~m}^{3}$. It has massive brick walls, vents drilled in vault, floor grilles and air ducts connected with cellar. The traditional, hot water heating system 
uses radiators installed underneath floor grilles and gas boiler located in a separate room, next to the sacristy. This system has a total capacity of $200 \mathrm{~kW}$ and very high operating costs, therefore it is not currently in use. Total heat demand of the University Church is approximately $485 \mathrm{~kW}$ and was calculated according to the paragraph 3.2 [12].

\subsection{Suggested methods for heating}

The article presents two different methods of heating: a warm air heating that uses existing equipment and a system specifically studied for conservation, called "friendly heating".

The first one refers to the previous solution of heating system, so it avoids interference in the structure of the building. Fresh air is provided by the ducts to the heating and ventilation units (HV), which are situated underneath the grilles. Recirculated air is sucked in through extreme parts of the grill to the HV. Every unit consists of a mixing box, a filter, an electrical air heater, a fan and an acoustic silencer. Warm mixture of fresh and recirculated air is supplied through central part of the floor grill with fixed air control blades and directed over people. This division of grills allows to reduce the impact of hot air on wooden benches.

In general, warm air tends to rise, damaging paintings on a vault. The remedy for convective heat losses and overheating frescos are jet nozzles, installed in existing vents. They are responsible for pushing the convective mass of air with return to the zone of human presence. Stale air from the building is exhausted to the attic.

Delivery of fresh air depends on the relative humidity $(\mathrm{RH})$ in the zone where people are present. If $\mathrm{RH}$ drops below reference value, the set of automatic regulation reduces influx of outside air. If relative humidity is still too low, regulator starts limiting temperature of blown air. It means that maintaining $\mathrm{RH}$ level in the church is superior to the thermal comfort [12]. Figure 1 shows the general idea of the warm air heating system in the University Church.

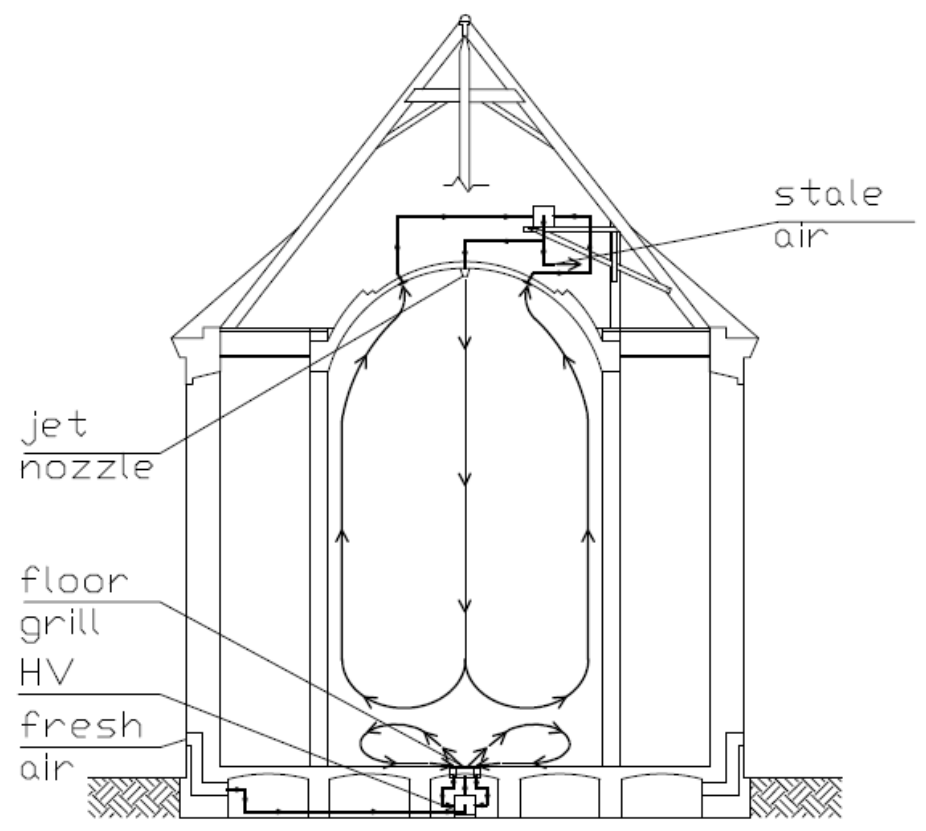

Fig. 3. Concept of a warm air heating system in the University Church. 
The natural microclimate in the University Church has preserved the internal artefacts in good condition. For this reason the second considered method is low radiant electric heating because of its minimal impact on the indoor air parameters. The heaters are strategically placed in every pew to heat people. Location of the radiators is important because it affects the visual effect and the feeling of thermal comfort. Figure 4 shows the most unobtrusive location of heaters. The drawback of this solution is that very small area of legs is directly affected.

The low radiant heaters cover 42 pews located in the main nave. They are divided into five heating sectors, the work of which depends on the number of people present at the service. Whereas, the heating foils are destined for a priest. They emit infrared radiation using the phenomenon of electrical resistance. The top layer may be a decorative carpet that protects the foil from mechanical damage. The concept of electrical heating system with section division inside the church is presented in Figure 5. [12].

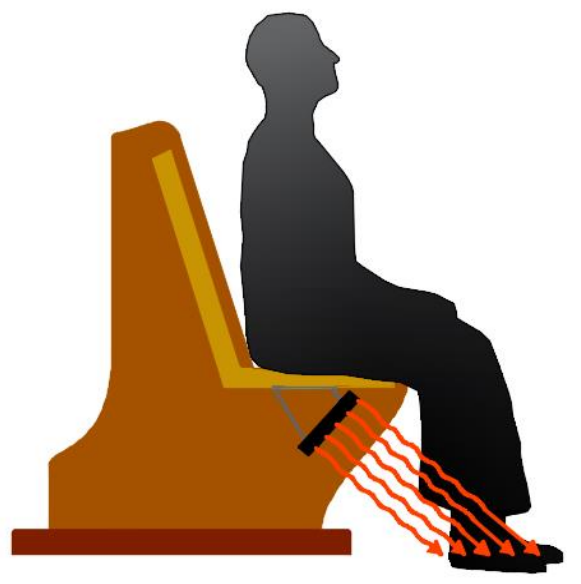

Fig. 4. The idea of low radiant electric heater fixed to a pew.

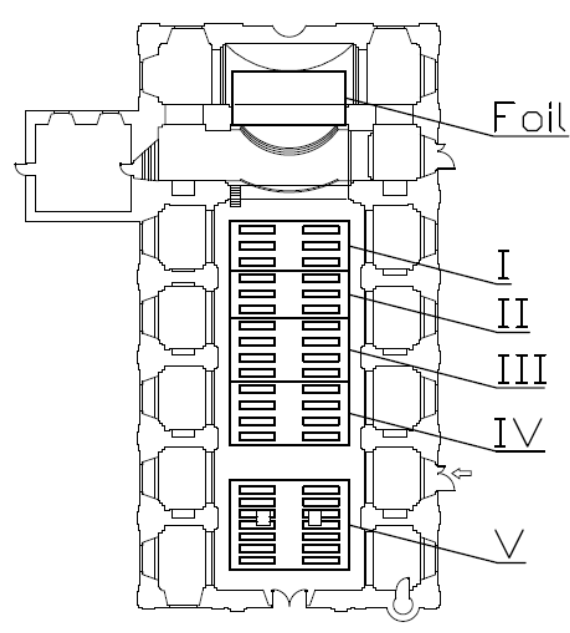

Fig. 5. Concept of the "friendly heating" in the University Church. Roman numerals means division into heating sectors.

\section{Conclusions}

Due to the specific construction of sacred buildings, designing heating and ventilation system requires an individual approach. It should be preceded by inspections of the air parameters in different seasons to determine the unique microclimate prevailing in the interior. Maintaining stable relevant humidity level is superior to the temperature level of air in a church. Controlling the operation of the heating system depends on the method of heating, outdoor conditions and operating costs. It is essential to avoid damages of historical artefacts, when designing the heating system. The effect of possible destructions, such as wood cracking or flaking of the paint coating, may be irreversible. Another problematic issue is lack of available, updated methods for calculating the total heat demand of churches. It is appreciated that each of heating system has its pros and cons. In this paper only two heating methods were considered, due to the possibility of using existing equipment (grills, vents, cellar) and creating appropriate conditions for historical artefacts in the University Church. In general: warm air heating system may cause shrinkage/swelling of hygroscopic materials and furthermore cracks, dispersion of the ash 
and also blackening ceiling and walls. Moreover, it generates high heat losses, cold downdrafts nearby walls and high sound power level during air flow through grills. Nevertheless it has a low operating costs and requires a short start-up time. It is worth noting that this system may allow control the air parameters in a church $(\mathrm{T}, \mathrm{RH})$ by adjusting volume of supplied external air and may reuse existing elements (ducts, vents, grills). On the contrary, low radiant electric heating has no influence to sensitive artefacts, dust deposition or cold downdrafts. It can be used only before and during services - it does not need a lot of time to start working properly. In addition, electric heaters can be divided into sections, and each section can be activated separately depending on the attendance of people. But implementation of this heating system may entail higher contracted capacity and, as a result, higher contracted capacity charge. In some cases it may be even impossible to implement the low radiant electric heaters because of the condition of the existing electrical installation in the church. Another drawback of this solution is inability to accumulate generated heat. There is no perfect solution. Moreover, it is useful to consider the technical feasibility of the analysed object. It allows for avoiding the interference in the structure of the building and aesthetic quality of the interior.

\section{References}

1. A. Chmielowski, Polski Instalator 3, 69-70 (1998)

2. L. Laskowski, Ciepłownictwo Ogrzewnictwo Wentylacja 1, 14-19 (1997)

3. B. J. Rouba, Chłodnictwo i Klimatyzacja 7, 48-56 (2017)

4. D. Camuffo, A. Della Valle, Church Heating: a Balance between Conservation and Thermal Comfort, (Contribution to the Experts' Roundtable on Sustainable Climate Management Strategies, 2007)

5. J.S. Johnson, the Museum Handbook. Part I: Museum Collections, 4, 14 (National Park Service, Museum Management Program, Washington, 1999)

6. EN ISO 7730 Ergonomics of the thermal environment-Analytical determination and interpretation of thermal comfort using calculation of the PMV and PPD indices and local thermal comfort criteria

7. D. Camuffo, Microclimate for Cultural Heritage- Conservation, Restoration, and Maintenance of Indoor and Outdoor Monuments, 1 (Elsevier Science, 2014)

8. R. Kozłowski, Ł. Bratasz, Konserwacja zapobiegawcza w muzeach, 155-164 (Warszawa, Krajowy Ośrodek Badań i Dokumentacji Zabytków, 2007)

9. Ł. Bratasz, Climate for Collections Standards and Uncertainties, 11-19 (Archetype Publications Ltd, 2013

10. M. Chapuis et al., Church heating and the preservation of the Cultural Heritage. Guide to the Analysis of the Pros and Cons of Various Heating Systems (Electa, 2007)

11. H. Recknagel, E. Sprenger, E. Schramek, Kompendium wiedzy. Ogrzewnictwo, klimatyzacja, ciepła woda, chłodnictwo, 1065-1070 (Omni Scala, Wrocław, 2008)

12. E. Pałupska, E. Przydróżny, Projekt wentylacji $i$ ogrzewania kościoła (BSc Thesis, Wydział Inżynierii Środowiska, Politechnika Wrocławska, 2016)

13. http://mib.gov.pl [access: 30.01.2018]

14. http://wosoz.ibip.wroc.pl/public/?id=92697 [access: 30.01.2018] 